\title{
Side effects of gadolinium MRI contrast agents
}

\section{Skutki uboczne kontrastów do MRI zawierających gadolin}

\author{
${ }^{1}$ Houston Methodist Research Institute, Houston, Texas, USA \\ ${ }^{2}$ Department of Surgery, Houston Methodist Hospital, Houston, Texas, USA \\ ${ }^{3}$ Electrical and Computer Engineering Department, University of Houston, Houston, Texas, USA \\ ${ }^{4}$ Texas Center for Superconductivity, University of Houston, Houston, Texas, USA \\ ${ }^{5}$ Department of Regenerative Medicine and Cell Biology, Military Institute of Hygiene and Epidemiology (WIHE), Warsaw, Poland \\ ${ }^{6}$ UnivRennes, UMR 6290, CNRS, Institute of Genetics and Development of Rennes (IGDR), Cell Cycle Group, Faculty of Medicine, Rennes, France \\ ${ }^{7}$ Department of Genetics, University of Texas, M.D. Anderson Cancer Center, Houston, Texas, USA \\ Correspondence: Malgorzata Kloc, Houston Methodist Research Institute, 6670 Bertner Ave, Houston, TX77030, USA, e-mail: mkloc@houstonmethodist.org
}

Abstract Magnetic resonance imaging is widely used as a diagnostic tool in the clinic. Magnetic resonance imaging contrast agents such as gadolinium are very often used to improve the quality of images acquired by magnetic resonance imaging. Until recently, it was believed that gadolinium is effectively cleared within 24 hours after intravenous injection, and that it does not have any harmful effects on the human body. However, recent studies on animals and analyses of clinical data have indicated that gadolinium is retained in the body for many years post-administration, and may cause various diseases. This is especially concerning for paediatric patients because of the anticipated longer time of exposure and its effects on children's continuing development, and patients who receive repeated magnetic resonance imaging scans and hence repeated doses of gadolinium. Here, we give a short review of the most recent findings on the accumulation and side effects of gadolinium.

Keywords: gadolinium, MRI, contrast, paediatric patients

Streszczenie

Rezonans magnetyczny to narzędzie diagnostyczne szeroko stosowane w praktyce klinicznej. Środki kontrastowe do obrazowania rezonansu magnetycznego, takie jak gadolin, są bardzo często używane w celu poprawy jakości obrazów uzyskiwanych za pomocą tego badania. Do niedawna uważano, że gadolin jest usuwany z organizmu w ciągu 24 godzin po podaniu i że nie ma żadnego szkodliwego wpływu na organizm ludzki. Niestety, ostatnie badania wskazują, że jest on zatrzymywany w organizmie nawet przez wiele lat po zastosowaniu i może powodować różne choroby. Jest to szczególnie niepokojące w przypadku pacjentów pediatrycznych, ponieważ gadolin może wpływać na procesy rozwojowe. Poniżej przedstawiamy krótki przegląd ostatnich badań nad akumulacją i skutkami ubocznymi gadolinu.

Słowa kluczowe: gadolin, MRI, kontrast, pacjenci pediatryczni 


\section{INTRODUCTION}

$\mathrm{M}$ agnetic resonance imaging (MRI) that implements the static magnetic field (1.5-7 T), switching gradients of the magnetic field, and radiofrequency (RF) electromagnetic radiation to produce images of the tissues and organs of interest, has become a widely used tool in the clinical diagnosis. Although many studies indicate otherwise ${ }^{(1,2)}$, MRI is commonly believed to be a non-invasive and non-destructive technique without any harmful side-effects on the human body.

To enhance the contrast and improve the quality of MRI images scientists and clinicians often (in 1 in 3 of MRI scans) use MRI contrast media such as gadolinium, which are intravenously injected into the patient's body before taking the image $e^{(3,4)}$.

Gadolinium was discovered in 1880 by the Swiss chemist Jean Charles de Marignac, and named after gadolinite, one of the minerals containing gadolinium, discovered by the Swedish/Finnish chemist and mineralogist Johan Gadolin. Gadolinium is a ductile rare-earth element strongly paramagnetic above $20^{\circ} \mathrm{C}\left(68^{\circ} \mathrm{F}\right)$. These paramagnetic properties allow the solutions of chelated organic gadolinium complexes to be used as contrast agents for $\mathrm{MRI}^{(3-5)}$. Although the ions present in the water-soluble salts of gadolinium are toxic to mammalian cells and tissues ${ }^{(6)}$, the chelated versions of gadolinium used for MRI were, until recently, believed to be far less toxic, as they were supposedly cleared from the body through the kidneys within 24 hours i.e. before the release of the toxic $\mathrm{Gd} 3+$ ions $^{(3,4,7)}$.

However, in recent years, both animal studies and analyses of clinical records have shown that gadolinium-based contrast agents not only fail to be rapidly removed from the body, but also they are toxic, especially if repeatedly used for frequently performed MRI scans ${ }^{(7-9)}$.

\section{ACCUMULATION OF GADOLINIUM IN ORGANS AND TISSUES}

Recent studies on the accumulation of gadolinium in rat organs and tissues ${ }^{(10)}$ showed that gadolinium derived from the disintegration of implanted pins made of a biodegradable magnesium-gadolinium alloy was retained in the rat body for over 36 weeks of the experiment. Strikingly, although the blood serum demonstrated no accumulation, gadolinium accumulated within the intramedullary cavity and the cortical bones, and disrupted bone remodelling. In addition, heavy accumulation of gadolinium was detected in the spleen, lung, liver and kidneys, and lower levels of accumulation in the brain, muscles, and heart. Another study on rats ${ }^{(11)}$ showed that 8 weeks after repeated administration the gadolinium-based contrast agent accumulated in the skin and brain, and, in some animals, caused fibrotic lesions of the skin. Yet another study found that gadolinium persisted in rat brains for at least 5 weeks after the injec- of gadolinium in the brain after the repeated administration of gadolinium-based MRI contrasts was especially strong in the globus pallidus, a structure that regulates voluntary movements, and the dentate nuclei (clusters of neurons located in the cerebellar hemispheres) $)^{(13,14)}$. Although the clinical significance or the adverse effects (if any) of gadolinium accumulated in the brain are, at present, unknown, the International Society for Magnetic Resonance in Medicine has issued new recommendations for the clinical and research applications of gadolinium-based contrast agents ${ }^{(15)}$. There are also reports of the accumulation of gadolinium in the bones. The patients who underwent heap replacement surgery showed gadolinium accumulation in the femoral bones as late as 8 years after the surgery ${ }^{(16,17)}$.

\section{DISEASES ASSOCIATED WITH GADOLINIUM}

Gadolinium-based contrasts have been linked to nephrotoxicity and nephrogenic systemic fibrosis (NSF), and progressive fibrosis of various organs and skin, especially in patients with advanced or chronic kidney disease $(\mathrm{CKD})^{(16,18,19)}$. It was also shown that the risk of developing NSF increased with the multiple administration or higher doses of gadolinium $^{(16,18,20)}$.

There are also reports of gadolinium neurotoxicity, such as haemorrhage and damage of the corpus callosum, myoclonus, ataxia, and tremor, in rats injected with a gadolinium-based contrast agent ${ }^{(16,21)}$. In humans, there are reports of encephalopathy developing after the administration of a gadolinium-based MRI contrast ${ }^{(16,22)}$.

The injection of gadolinium-based MRI contrast agents can also lead to acute toxicity and damage immediately post-injection. Bertin et al. ${ }^{(23)}$ reported an incident of interstitial pulmonary toxicity and acute intra-alveolar haemorrhage in a patient injected with gadolinium. Interestingly, this acute pulmonary toxicity of gadolinium mimicked the effect of the injection of glycoprotein IIb/IIIa inhibitors which are used for the treatment of acute coronary syndrome ${ }^{(24)}$.

\section{EFFECTS OF GADOLINIUM IN CHILDREN}

Especially concerning should be the potentially harmful effects of gadolinium-based MRI contrast agents in children. Paediatric patients, especially very young children, foetuses, and neonates, with immature renal functions, are at a higher risk of developing nephrogenic systemic fibrosis ${ }^{(25)}$. Although paediatric data on the effects of gadolinium are very scarce, they are reports of gadolinium retention in the brain, especially high in the globus pallidus, of paediatric patients (1-13 years old) ${ }^{(26)}$. While it is yet unknown what the long-term effects of gadolinium accumulation in children, foetuses, and neonates are, these groups are potentially at a considerably higher risk than adults because of the anticipated longer time of exposure and effects on children's continuing development ${ }^{(9)}$. 

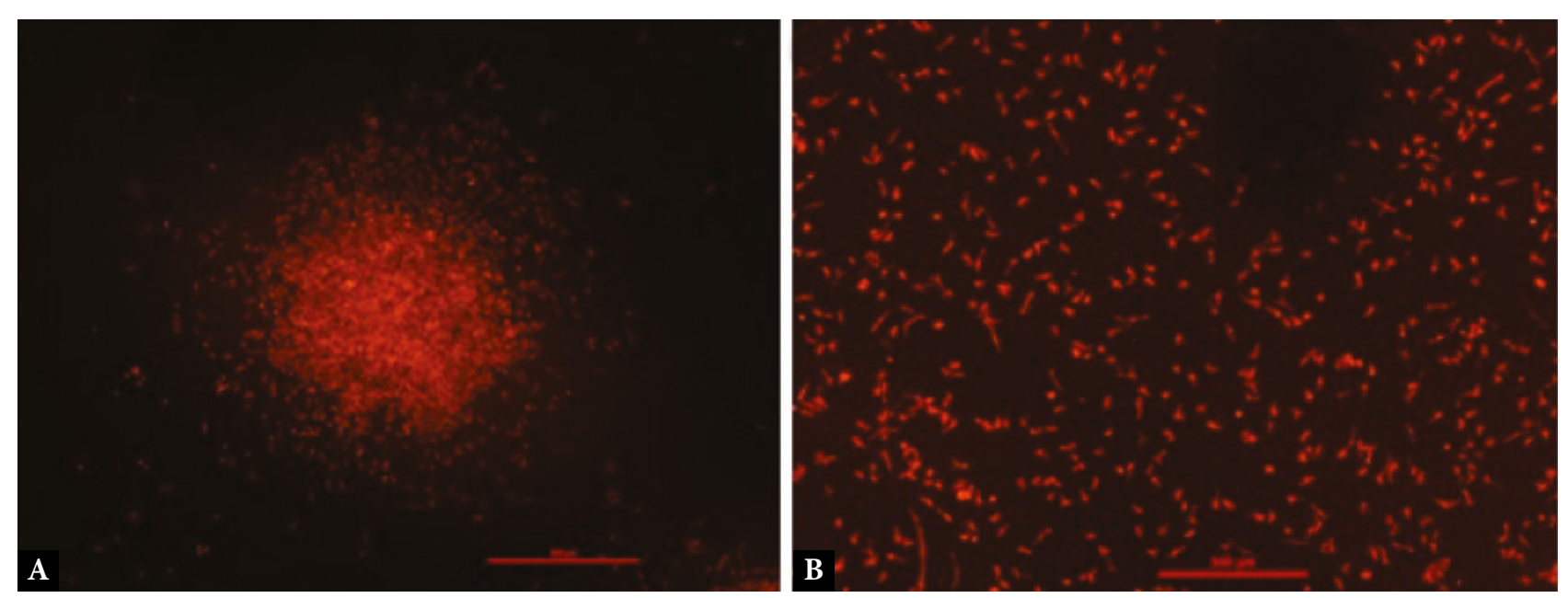

Fig. 1. The effect of gadolinium on the magnet-exposed mouse peritoneal macrophages. Mouse peritoneal macrophages exposed to the magnet in the presence (A) or absence (B) of $40 \mathrm{mM}$ gadolinium MRI contrast agent. In the presence of gadolinium, macrophages moved toward, and aggregated at the peak of the magnetic force. Macrophages were stained for actin with rhodamine-phalloidin (red). The bar is equal to $500 \mu \mathrm{m}$.

\section{EFFECTS OF GADOLINIUM ON MAMMALIAN CELLS}

There have been several in vitro studies on the effect of gadolinium on various types of mammalian cells, which may explain nephro- and neurotoxicity of gadolinium. For example, the epithelial cells from the proximal renal tubules (LLC-PK1 cells) underwent apoptosis and necrosis after 24-hour exposure to different gadolinium-based contrast agents ${ }^{(27)}$. Studies on the cerebellar Purkinje cells and monkey kidney CV-1 cells showed that gadolinium-based contrasts decreased or inhibited thyroid hormone-mediated transcription, which, in vivo, regulates the development and functions of the central nervous system ${ }^{(28)}$. Studies by Bower et al. ${ }^{(29)}$ found that gadolinium-based contrasts affected the mitochondrial respiration and viability of cultured human neurons.

Not unexpectedly, gadolinium also produces toxic effects on immune cells including macrophages. A study on RAW 264.7 mouse macrophages showed that gadolinium-based contrasts inhibited the mitochondrial membrane potential, and induced the production of reactive oxygen species (ROS), nitrate/nitrite, and prostaglandin E2 (PGE2). It also changed their inflammatory response; the LPSstimulated macrophages produced a higher level of nitrite/nitrate, and had suppressed secretion of IL- $1 \beta$, IL-6, IL-10, and TNF- $\alpha$.

Preliminary studies from our laboratory showed that the peritoneal mouse macrophages exposed in vitro to a strong magnetic field gradient in the presence of a gadoliniumbased contrast migrated toward the peak of the gradient and accumulated into large multicellular aggregates (Fig. 1). This finding suggests that, also in vivo, gadolinium in combination with the MRI-induced magnetic field may change the migratory behaviour of immune cells and modify the immune response in humans.
Further studies on the effect of gadolinium-based contrasts on human macrophages and other immune cells may shed the light on how gadolinium-affected immune system amplifies or propagates gadolinium toxicity, and promotes the development of various diseases in humans exposed to MRI contrasts.

\section{PROSPECTS}

Because of the toxicity and potential adverse long-term effects of gadolinium-based contrast agent accumulation in the body, the latest efforts have been targeted at the development of novel strategies, such as liposome-encapsulated gadolinium contrasts, and the integration of gadolinium into various nanocarriers ${ }^{(30)}$, which may improve the safety of gadolinium-based MRI contrast agents.

\section{Conflict of interest}

The authors do not report any financial or personal affiliations to persons or organisations that could adversely affect the content of or claim to have rights to this publication.

\section{Acknowledgments}

While writing this article, JZK was supported by the Polish Ministry of National Defence (MON) project "Kościuszko" no: 508/2017/DA.

\section{References}

1. Formica D, Silvestri S: Biological effects of exposure to magnetic resonance imaging: an overview. Biomed Eng Online 2004; 3: 11.

2. Panych LP, Madore B: The physics of MRI safety. J Magn Reson Imaging 2018; 47: 28-43.

3. Ibrahim MA, Gupta N, Dublin AB: Magnetic Resonance Imaging (MRI) Gadolinium. [Updated 2020 Jan 12]. In: StatPearls [Internet]. StatPearls Publishing, Treasure Island (FL) 2020. Available from: https://www.ncbi.nlm.nih.gov/books/NBK482487/. 
4. Xiao YD, Paudel R, Liu J et al.: MRI contrast agents: classification and application (Review). Int J Mol Med 2016; 38: 1319-1326.

5. Coey JMD, Skumryev V, Gallagher K: Rare-earth metals: is gadolinium really ferromagnetic? Nature 1999; 401: 35-36.

6. Akhtar MJ, Ahamed M, Alhadlaq $\mathrm{H}$ et al.: Toxicity mechanism of gadolinium oxide nanoparticles and gadolinium ions in human breast cancer cells. Curr Drug Metab 2019; 20: 907-917.

7. Lancelot E: Revisiting the pharmacokinetic profiles of gadolinium-based contrast agents: differences in long-term biodistribution and excretion. Invest Radiol 2016; 51: 691-700.

8. Garcia J, Liu SZ, Louie AY: Biological effects of MRI contrast agents: gadolinium retention, potential mechanisms and a role for phosphorus. Philos Trans A Math Phys Eng Sci 2017; 375: 20170180.

9. Pasquini L, Napolitano A, Visconti E et al.: Gadolinium-based contrast agent-related toxicities. CNS Drugs 2018; 32: 229-240.

10. Myrissa A, Braeuer S, Martinelli E et al.: Gadolinium accumulation in organs of Sprague-Dawley ${ }^{\circ}$ rats after implantation of a biodegradable magnesium-gadolinium alloy. Acta Biomater 2017; 48: 521-529.

11. Lohrke J, Frisk AL, Frenzel T et al.: Histology and gadolinium distribution in the rodent brain after the administration of cumulative high doses of linear and macrocyclic gadoliniumbased contrast agents. Invest Radiol 2017; 52: 324-333.

12. Jost G, Frenzel T, Boyken J et al.: Gadolinium presence in the brain after administration of the liver-specific gadolinium-based contrast agent gadoxetate: a systematic comparison to multipurpose agents in rats. Invest Radiol 2019; 54: 468-474.

13. Kanda T, Ishii $\mathrm{K}$, Kawaguchi $\mathrm{H}$ et al.: High signal intensity in the dentate nucleus and globus pallidus on unenhanced T1-weighted MR images: relationship with increasing cumulative dose of a gadolinium-based contrast material. Radiology 2014; 270: 834-841.

14. Moser FG, Watterson CT, Weiss $S$ et al.: High signal intensity in the dentate nucleus and globus pallidus on unenhanced T1-weighted MR images: comparison between gadobutrol and linear gadolinium-based contrast agents. AJNR Am J Neuroradiol 2018; 39: 421-426.

15. Gulani V, Calamante F, Shellock FG et al.; International Society for Magnetic Resonance in Medicine: Gadolinium deposition in the brain: summary of evidence and recommendations. Lancet Neurol 2017; 16: 564-570.

16. Rogosnitzky M, Branch S: Gadolinium-based contrast agent toxicity: a review of known and proposed mechanisms. Biometals 2016; 29: 365-376.

17. Darrah TH, Prutsman-Pfeiffer JJ, Poreda RJ et al.: Incorporation of excess gadolinium into human bone from medical contrast agents. Metallomics 2009; 1: 479-488.
18. Marckmann P, Skov L, Rossen K et al.: Nephrogenic systemic fibrosis: suspected causative role of gadodiamide used for contrast-enhanced magnetic resonance imaging. J Am Soc Nephrol 2006; 17: 2359-2362.

19. Takahashi EA, Kallmes DF, Mara KC et al.: Nephrotoxicity of gadolinium-based contrast in the setting of renal artery intervention: retrospective analysis with 10-year follow-up. Diagn Interv Radiol 2018; 24: 378-384.

20. Perazella MA: Gadolinium-contrast toxicity in patients with kidney disease: nephrotoxicity and nephrogenic systemic fibrosis. Curr Drug Saf 2008; 3: 67-75.

21. Ray DE, Cavanagh JB, Nolan CC et al.: Neurotoxic effects of gadopentetate dimeglumine: behavioral disturbance and morphology after intracerebroventricular injection in rats. AJNR Am J Neuroradiol 1996; 17: 365-373.

22. Hui FK, Mullins M: Persistence of gadolinium contrast enhancement in CSF: a possible harbinger of gadolinium neurotoxicity? AJNR Am J Neuroradiol 2009; 30: E1.

23. Bertin L, Guillet $\mathrm{H}$, Aloui $\mathrm{K}$ et al.: Diffuse alveolar hemorrhage after gadolinium injection during a MRI. Respir Med Case Rep 2020; 29: 101021.

24. Mikkilineni H, Bruhl SR, Colyer WR et al.: A retrospective analysis and case series of glycoprotein IIb/IIIa inhibitor associated diffuse alveolar hemorrhage: two case reports. Cases J 2009; 2: 8553.

25. Meng H, Grosse-Wortmann L: Gadolinium in pediatric cardiovascular magnetic resonance: what we know and how we practice. J Cardiovasc Magn Reson 2012; 14: 56.

26. Stanescu AL, Shaw DW, Murata $\mathrm{N}$ et al.: Brain tissue gadolinium retention in pediatric patients after contrast-enhanced magnetic resonance exams: pathological confirmation. Pediatr Radiol 2020; 50: 388-396.

27. Heinrich MC, Kuhlmann MK, Kohlbacher S et al.: Cytotoxicity of iodinated and gadolinium-based contrast agents in renal tubular cells at angiographic concentrations: in vitro study. Radiology 2007; 242: 425-434.

28. Ariyani W, Iwasaki T, Miyazaki W et al.: Effects of gadoliniumbased contrast agents on thyroid hormone receptor action and thyroid hormone-induced cerebellar Purkinje cell morphogenesis. Front Endocrinol (Lausanne) 2016; 7: 115.

29. Bower DV, Richter JK, von Tengg-Kobligk $\mathrm{H}$ et al.: Gadoliniumbased MRI contrast agents induce mitochondrial toxicity and cell death in human neurons, and toxicity increases with reduced kinetic stability of the agent. Invest Radiol 2019; 54: 453-463.

30. Marasini R, Thanh Nguyen TD, Aryal S: Integration of gadolinium in nanostructure for contrast enhanced-magnetic resonance imaging. Wiley Interdiscip Rev Nanomed Nanobiotechnol 2020; 12: e1580. 